\title{
A spatial analysis of motorcycle taxis activities for environmental planning - The case of Port-au- Prince, Haiti
}

\author{
[Rémi Jaligot, Armel Kemajou, Jérôme Chenal]
}

\begin{abstract}
We report a novel method for the spatial analysis of informal transport activities for future environmental planning. It uses a combination of spatial data gathered with GPS devices and semi-formal interviews. We show that the current configuration of the system is not optimized. It leads to a greater concentration of motorcycle taxis activities in denser urban areas, emitting high levels of noise and air pollution. Recommendations include decentralizing part of the activity and closer monitoring of the number of pilots.
\end{abstract}

Keywords - Spatial analysis, motorcycle taxis, urban transport, developing countries, environmental planning

\section{Introduction}

Motorcycle taxis are a mode of public transport undergoing major expansion in developing countries $[1,2$, and 3]. Urban sprawl, difficult economic times and demographic pressure led part of the population of the Republic of Haiti to use this practical and cheap mode of transport $[4,5]$. However, motorcycle taxis operate in a nonregulated and uncontrolled environment, creating major public health, environmental and economic challenges [6, 7]. Environmental planning is essential to improve living conditions. The aim of this study is to gain an in-depth understanding of motorcycle activities for future environmental planning in Port-au-Prince. This study is of exploratory nature and presents a dual approach including the spatial analysis of motorcycle taxi trips by GPS tracking and semi-formal interviews.

\section{Study Area}

The study area covers $735.78 \mathrm{~km}^{2}$ and includes eight municipalities of the metropolitan area of Port-au-Prince, namely Carrefour, Cité-Soleil, Delmas, Gressier, Kenscoff, Pétion-Ville, Port-au-Prince and Tabarre (Fig. 1).

Rémi Jaligot, Armel Kemajou, Jéròme Chena Swiss Federal Institute of Technology, Lausanne Switzerland

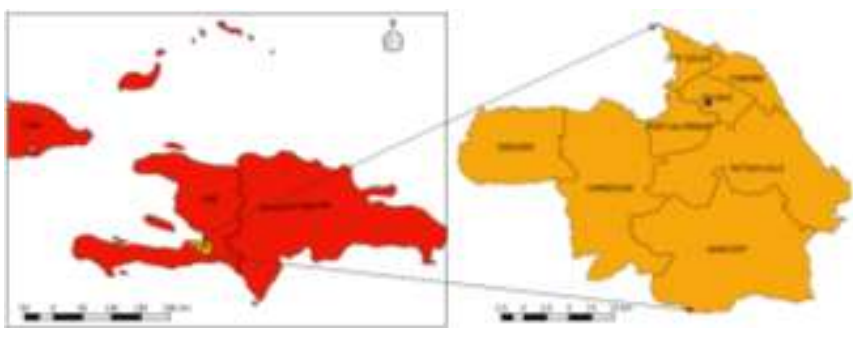

Fig 1. Study area.

Orange zones represent municipalities in the metropolitan area of Port-au-Prince. The blue dot shows the location of data gathering at the Delmas 31 stand.

\section{Methodology}

The selection of a suitable stand of motorcycle taxis for this study was based on two main criteria, the size of the stand and the feasibility. The stand named Delmas 31, located municipality of Delmas, occupies a central location in the inter-municipal commuting network. The collection of spatial data included geographical coordinates, speed, time and altitude. The selection of motorcycle taxis pilots was based on three criteria: seniority, experience and carefulness in conducting their activity. Twelve pilots were selected out of a sample of fifty candidates, all working from the Delmas 31 stand. Fully charged GPS tracking devices were supplied on a daily basis.

The method of Haversine [8] were implemented in RStudio 3.3.3@ , and allowed obtaining the total distance travelled as well as the distance travelled for each trip. Combining this result with speed, time and location data allowed obtaining the maximum action range, the median action range and the rate of inactivity. A visual representation of daily trips was also used to estimate the distribution of motorcycle taxis on the territory. In addition, a semi-formal interview was conducted daily with a pilot to gather qualitative data, and optimize the analysis of quantitative data.

\section{Results}

The median action range (Fig 2.) is limited to $2.35 \mathrm{~km}$, with $80 \%$ of all trips taking place within a $3-\mathrm{km}$ radius. It is associated with the poor distribution of motorcycle taxis on the territory, which is likely to create major environmental challenges in the center of the metropolitan area. The high density of working vehicles in a limited action range leads to an increase of air population in a densely populated area, where the population lives and work outdoors. In addition, 
our results show that motorcycle taxis remain idle for more than fifty percent of the working period, some leaving their engine on. Large amounts of noise and air pollution are further emitted in the dense urban center.

\section{v. Discussion and Conclusion}

The activity does not appear to be optimized by the current configuration of the system partly, due to the large number of pilots. A poor distribution of stands of motorcycle taxis on the municipal territory also fosters the lack of effectiveness and efficiency in the system, leading high concentration of vehicles in the denser areas of the urban region.

The research recommends that some stands should be decentralized to balance the supply, especially towards peripheral areas, as well as more efficient monitoring of the number of pilots. It would allow lowering the concentration of air pollutants in densely populated urban areas, and improving the availability of services for urban dwellers living in peripheries.

The methodology is exploratory in nature. It shows effectiveness, robustness and transparency to address some challenges of environmental planning in a developing country. Some limitations are pointed out for transparency and future research. For example, it would be interesting to reproduce a similar study at a larger scale in several stands located both in central areas and in peripheral areas, simultaneously.

\section{Acknowledgment}

The authors wish to thank Carline Joseph Duval and Dr Anie Bras Jopesh at Quisqueya University in Port-au-Prince, for helpful advices and assistance related to the fieldwork in Haiti. All views expressed in this paper are those of the authors alone.

\section{References}

[1] Al-Hasan, A. Z., Momoh, M., \& Eboreime, L. (2015). Urban poverty and informal motorcycle transport services in a Nigerian intermediate settlement: a synthesis of operative motives and satisfaction, Urban, Planning and Transport Research, 3:1, 1-18

[2] Garuba, D. S. (2006). Survival at the margins: Economic crisis and coping mechanisms in Rural Nigeria. Local Environment, 11, 17-36.

[3] Olvera, L. D., Plat, D., Pochet, P., \& Maïdadi, S. (2012). Motorbike taxis in the" transport crisis" of West and Central African cities. EchoGéo, (20).

[4] Chery, R. (2015.) Haïti société/ Circulation/ Moto-taxi Vie d'un chauffeur de moto-taxi. Quotidien Le National. Retrieved from: http://www.lenational.org/haiti-societe-circulation-moto-taxi-viedunchauffeur-de-moto-taxi/.

[5] Rameau, R. (2014). Un système de transport adapté aux besoins de circulation à Port-au-Prince. Problématique des transports à Port-auPrince. Retrieved from haitiperspectives.com: http://www.haitiperspectives.com/pdf/3.2-systeme.pdf.

[6] Haley, J. M. \& Cone, P. H. (2016). Mobile clinics in Haiti, part 2: Lessons learned through service. Nurse Education in Practice, 21, 66-74.

[7] McLaughlin, N., \& Rogers, H. (2013). Helping Haiti’s transportation issues: increasing Haiti's medical liabilities. Journal of Global Health, 3(1).

[8] Chen, M., Sohn, T., Chmelev, D., Haehnel, D., Hightower, J., Hughes, J., LaMarca, A., Potter, F., Smith, I., \& Varshavsky, A.
(2006). Practical metropolitan-scale positioning for gsm phones. UbiComp 2006: Ubiquitous Computing, 225-242

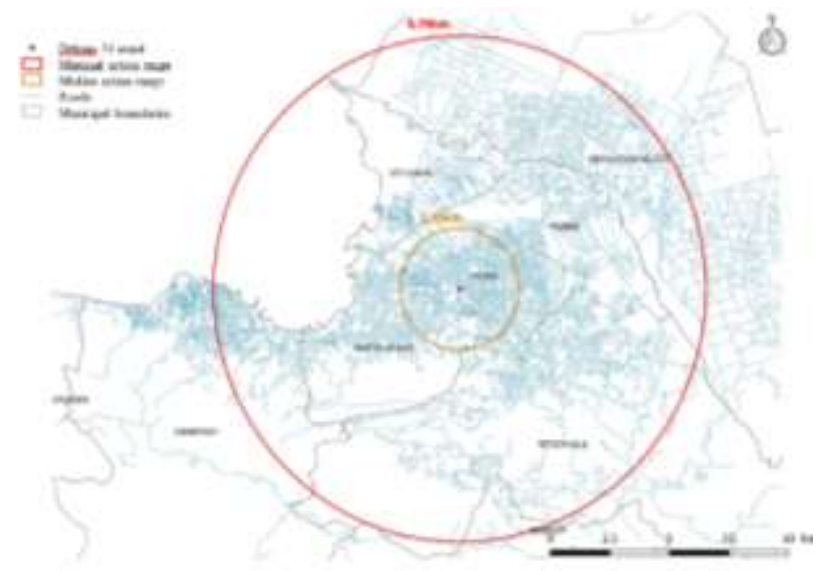

Fig 2. Action ranges of motorcycle taxis in Port-au-Prince, Haiti.

\section{Quote}

The high density of working vehicles in a limited action range leads to an increase of air population in a densely populated area, where the population lives and work outdoors. 